Cracow Indological Studies

vol. XV (2013)

10.12797/CIS.15.2013.15.19

\title{
Courtly Culture and Political Life in Early Medieval India. By Daud Ali. Delhi: Cambridge University Press, 2006. xx + 296 pp. \$ 30.00 (hardcover)-
} Reviewed by Piotr Borek (Jagiellonian University, Kraków)

Contemporary scholars carrying out research on pre-modern India are readily conscious of the elusive nature of South Asian historiography. For at least two decades they have been seeking for some adequate methodologies to proceed with the reconstructions of that still unexplored world. This quest concerns predominantly the literary sources as previously they had been treated for long with no major attempts to use them as fit for holistic social or historico-political reconstructions. The book of Daud Ali, Courlly Culture and Political Life in Early Medieval India is a courageous and one of the first comprehensive propositions to exploit the literature with the hope it could serve the important purpose to represent the social history of a part of the pre-colonial world.

\section{STRUCTURE AND SUBJECT}

The book opens with a list of figures, acknowledgments, a list of abbreviations-most essential, given the abundance of sources referred 
to later, a glossary of the key Sanskrit terms and a theoretical introduction. The main text is divided into three parts: I. The Rise of Court Socicty in Medicval India, II. Aesthetics and the Courtly Sensibility, III. Courtly Love and Aristocratic Socicty. The first and longest part (pp. 29-140) comprises three chapters. Parts II (pp. 143-206) and III (pp. 209-261) composed of two chapters each are followed by ten pages of "conclusions and further directions" (pp. 262-271). A rich bibliography divided into an impressive list of primary sources (texts and translations-pp. 272-280 and epigraphic and numismatic material-pp. 280-281), secondary works (pp. 281-289) is followed by a surprisingly short index of names and terms (pp. 290-296).

During the lecture of subsequent chapters, one may have an impression that Ali deals with one specific court, but this is not the casc. The temporal span of sources does not allow for a precise determination of the boundaries. Therefore, the book envisages presenting a set of themes and concerns common for the courtly culture developed over around a millennium. This culture has been shown as the one that originates in the court of the Mauryas (320-185 BCE). Many sources concern the post-Aśokan dynasties of North and Middle India, but the crystallization of this culture is to be scen under the Guptas and other rulers from the $4^{\text {th }}$ to the $7^{\text {th }}$ centuries CE. The latest caesura of the early medieval times is understood here as the period preceding immediately the coming to power of Muslim rulers. For "From the establishment of the Delhi Sultanate in the early thirteenth century, this culture was partially and gradually re-articulated in 'vernacular' languages which transformed and extended them, often now in open or implicit dialogue with the practices of Islamic polity" (p. 20).

One should not omit the short text of acknowledgments, where the author reveals the first motive for writing the book. He repeats after Martha Selby that "while nearly all of Sanskrit poetry was courtly in nature, courtly life has remained untreated in both historical and literary scholarship" (p. xiii). The early medieval Sanskrit courtly literature, which serves as empirical evidence for Daud Ali's study, had already been explored extensively before him, but no existing 
scholarship shows any real attempts to use those sources to build a picture of social or political relations of that world; whereas, in fact, the purpose of the author was to use both the widely spread literary and, to a limited extent, visual sources to draw the complex courtly social relations which constitute an important part of the state's life and its politics. The novelty of the study comes from an attempt to provide a remedy for the problem with the existing kāvya scholarship which lies in the fact that " $(\ldots)$ those who have treated the social contexts of literary and aesthetic texts have by and large paid scant attention to the content of these sources, while those preoccupied with their content have done so with very little regard for context" (p. 13).

\section{METHODOLOGY}

Given the above-mentioned author's agreement with the critique of the kāvya scholarship, one expects the book to combine or compare both content and context. Certainly, the author does it to some extent, but I am a bit unconvinced about the way the latter has been explored. I think the book does not really solve the problem of methodology that would enable the drawing of some clear structures of the context under discussion. The methodology, as Daud Ali heralds in the introduction, consists in using literary sources in two ways: "First, they will be used empirically (and hopefully not naively!) to assist in reconstructing the context into which they must then be placed to a much greater degree than Goodwin has done [...]". He also hopes "to treat literary texts analytically as modes through which individuals were 'educated' and 'interpolated' into the structure of courtly life in a highly reflexive manner. And, rather than exalting the 'literary', [he hopes] instead to place literature within a wider set of aesthetic practices and ethical cultivations which where concerned with the body, the mind and the world" (p. 18). The lecture of the three parts of this book shows emphatically the author's reliance on the content of the sources, the context being still underexplored. The assumption that "literary texts corroborate many practices known from prescriptive literature, and thus, if read critically, can serve as useful evidence 
in reconstructing the world of the court" (p. 18) does not always prevent the reader from the concem of the self-referential tautological character of the first, so-called empirical method. Based on the kāvya content, the picture of the social relations looks like a complete one but there is nothing convincing that would show which parts of it are descriptive and which normative. So, I would say it is hard to find passages where the logic of the book does not replicate one of the most striking problems with many kāvya texts. On the other hand, I would say the success of the book lies rather in the second, i.e. analytical way of treating the literary sources. It follows Sheldon Pollock's theory of kāvya as the aestheticizing power, or literature that has constantly both shaped and been shaped by politics. And that is what binds together all seven chapters of this volume. The application of this method justifies (or vice versa) a general proposition that "courtly culture should not be seen as a bland form of legitimatory discourse but rather a complex set of practices which were formative and constitutive of political life in early medieval India" (p. 24). Daud Ali encourages his readers to perceive the state as an entity that arises from activities of individuals rather than some self-evident structure. Therefore, the royal court is not only "a symbol of the state but a superordinate set of human relationships" (p. 7). In this sense, the criticism of legitimation theory or patronage model, "which assumes a very impoverished court sociology, one dominated by the simple figure of the king/patron" (p. 15), makes this book also an important challenge to the status quo of social studies.

\section{SOURCES AND CONTENT}

Daud Ali used four types of material for his study: treatises on politics, love and aesthetics; dramatic, narrative and illustrative works; stone and copperplate epigraphical inscriptions; didactic and gnomic sayings, aphorisms and single stanza poems. All of them claim affinity to the wide category of kāvya literature. Although their bibliographical list is long (71 texts, some of them in multiple editions), the problematized narrative has been constructed with the predominant 
use of only a few of them, the remaining ones mostly furnishing odd details of the picture of the culture. Besides the inscriptions from the Corpus Inscriptionum Indicarum and South Indian Inscriptions, Kāmasūtra, Arthaśāstra, Nìtisāra and Bāṇa's Harșacarita are the most extensively explored sources and they constitute the main "corpus of evidence" (p. 143) for the attempted reconstruction. Frequent references to Mānavadhārmaśastra and Mānasollāsa, as well as to Bāṇa's Kādambarī and three other dramas: Kālidāsa's Mālavikāgnimitra, Śudraka's Mrcchakatika and Višākhadatta's Mudrārākșasa are to be observed mostly in the chapters of the first part. Additionally, there are also references to Raghuvamsia in the second part, or for instance to Ānandavardhana's Dhvanyäloka and other poetical treatises on the pages dedicated to the questions of refinement of speech, or those to gnomic literature in the last part of the book dedicated to erotic love.

The first chapter titled The people of the court deals with the personal structure of the royal household, including the architecture of the royal entourage and its relationship with the urban society. Starting with the description of the digvijaya martial ritual, it reveals to the reader many interesting phenomena that might have been true about the nature of wars in the early medieval India. Just to give a taste of what kind of data we may acquire from the study of the court structure, I propose to have a look at a short passage devoted to the customs of the Gurjara-Pratihāras, Pālas, Rāṣṭrakūṭas, Cālukyas, Cōlas and Paramāras. Thanks to the observation of the hierarchy of people inhabiting or frequenting the court, one may notice for instance. that "The battles fought between these imperial houses rarely resulted in or even had as their goal the direct annexation of substantial territory any great distance from the core regions of these kingdoms" (p. 32). Similarly, one may find here a plethora of details about the nature of kanyādāna custom, functions of goșthis, honouring the new weavers coming to settle down in the town, or princely rights to succession. Daud Ali pays attention to the fact that the descriptions of those rights or customs must be to some extent a view on how it should be rather than how it really 
was. So it is here that the reader may, for the first time, become suspicious whether the information provided is, an idealistic view or just a normative one. Chapter 2, The culture of the court is an account of worldly knowledge, the ways it was shared by the courtly circles and its overwhelming and practical to the core applicability in everyday life. It proposes also to look at the high level of courtly morality, again the demonstrations of power as part of the courtly code and the codified means of incorporating the barbarians into élite circles. The last chapter of the first part is devoted to manners, i.e. honours exchanged, courtesies, protocols and mostly their implementation in courtly procedures. The main idea of this article is to explore "the dynamics of the sources to show the important social significance of courtly practices which have been seen as entirely 'spiritual' in content." (p. 104).

The courtly concept of beauty-bodily, external, verbal and ethical is the subject of the fourth chapter. Here again Ali defends the innovativeness of his study, this time by setting himself against the orientalist thought, by saying that "the existing traditions of scholarship have tended to understand courtly aesthetics - and omament in particularas either a debased form of aesthetic perception (...), or alternatively as part of a holistic humanist and/or spiritual 'view of life' typical of Romantic modes of thinking" (p. 175). Apart from providing us with many interesting details on the early medieval standards of beauty drawn from kāvya literature, the author concludes in line with his preliminary theoretical assumptions that "aestheticized lifestyles of men and women of rank - the obsession with beautifying themselves and their surroundings-formed the means through which they acted upon themselves as well as negotiated their relations with others in the wider world of the court" (p. 182). The next chapter concerns the questions of élites' education supported by literature, with an emphasis on the rasa substract "or aesthetic savour, [which] fostered not only a reposeful 'delectation of sentiment, but also a mobile or itincrant subjectivity with regard to the affective relations which constituted courtly life" (p. 23). 
The last two chapters, also the shortest, of the volume concern the questions of love. Chapter 6, Courtship and the royal household, focuses on the sexual relationships of courtly, as well as urban, society. In the last chapter, Anxiety and romance in court society, devoted to the inner language of love, Ali argues that "through a close attention to the courtly commentary on erotic pleasure as well as to the language used to denote wider courtly affiliations, it is possible to show why erotic love remained the preferred topic of courtly poetry." And the reason of the courtly predilections for this subject, according to him, is that "people at court preferred to 'think' about wider social relationships through the world of crotic love." (pp. 234-235).

An easy-to-read narrative follows quite a heavy theoretical introduction. Therefore, at first sight the structure of the book seems stunning and can make the reader suspicious of its academic value. One receives almost a complete picture of the social courtly society of the distant world, noteworthily based only on kāvya literature, including the epigraphical inscriptions. How is it possible to reconstruct such a picture with no use of proper historiographical and archeological evidence? More so, being aware of the post-modern criticism of history writing-would it be feasible even with such "serious" proofs? Risky and controversial as it may appear, I find the author's concept of the book justified by the fact that it serves to lay the ground.

Although a few years have passed since the book was released, it is still useful in the sense that it encourages scholars dealing with pre-modern India to proceed with non-standard methods required by the nature of the sources. Considering that the aim is to fill a gap in the picture of Indian past, Ali's book proves useful and inspiring in spite of the method that may still be controversial not only from the point of view of conservative scholars. Apart from the theoretical introduction, the whole text reads smoothly, sometimes too smoothly, and leaves us anxious as to whether such a ceaseless narrative is indeed possible and reliable. But Daud Ali constantly reminds us that this book is a kind of primer. And the picture he draws should serve as a starting point or reference to further, more detailed research. In this matter 
he is overwhelmingly sincere and his honesty is no doubt the crucial trait of this study, making it reliable per se or fulfilling the fundamental academic requirements. Read without footnotes, introduction and concluding remarks, one has an impression that the majority of the passages could be compiled into a pleasant belles-lettres narrative. It is the reader's constant awareness of what has been said in the theoretical parts that makes the book an academic study and to some extant a methodological guide as well.

Courtly Culture and Political Life in Early Medieval India by Daud Ali is an interesting, not always convincing but at least partially successful experiment with methods of reconstructing the pre-modern world with the help of literature. Besides its values for Indologists who struggle with the methodology as a constantly tested and never firm ground, it is highly recommended for all those, including undergraduate students, who long for any holistic image of the Indian court, old manners and life satiated with beauty and moral values. Though one should never forget that, in terms of what is true or false, the world described by Daud Ali is but one of the possible historical representations.

Piotr Borek piotr.borek@me.com 